\title{
Replacement of sodium silicate-based alkali activator by rice husk ash in geopolymer production
}

\section{Siriwan Chokkha ( $\nabla$ siriwan@sut.ac.th )}

Suranaree University of Technology Institute of Engineering

Jiratchaya Ayawanna

Suranaree University of Technology Institute of Engineering

Anurat Poowancum

Suranaree University of Technology Institute of Engineering

\section{Research Article}

Keywords: Geopolymers, Compressive strength, Sodium silicate-free, Rice husk ash, Sustainability, Waste

Posted Date: February 18th, 2022

DOI: https://doi.org/10.21203/rs.3.rs-1215957/v1

License: (1) This work is licensed under a Creative Commons Attribution 4.0 International License.

Read Full License 


\section{Abstract}

Rice husk ash was used as an active-SiO ${ }_{2}$ source for the production of low-cost metakaolin based geopolymer. For cost reduction, active-SiO${ }_{2}$ from husk ash was used as an alternative $\mathrm{Na}_{2} \mathrm{SiO}_{3}$ activator replacement. The starting materials such as metakaolin, husk ash and $\mathrm{NaOH}$ with $\mathrm{SiO}_{2} / \mathrm{Al}_{2} \mathrm{O}_{3}$ ratios of $1.58-1.95$ were studied and calculated by XRF results. The fast hardening of geopolymer from husk ash occurred after curing at room temperature for $24 \mathrm{hrs}$. The strength of all samples was enhanced by increasing the amount of active-SiO ${ }_{2}$ from husk ash. The geopolymer from husk ash with $\mathrm{SiO}_{2} / \mathrm{Al}_{2} \mathrm{O}_{3}$ ratio of 1.95 showed high compressive strength with a value of $25 \mathrm{MPa}$. The production cost of geopolymer from husk ash was decreased with the value of $84.78 \%$. Husk ash is an alternative natural active-SiO${ }_{2}$ for replacing $\mathrm{Na}_{2} \mathrm{SiO}_{3}$ activator in the geopolymer manufacturing process, indicating a decrease in the cost of the process.

\section{Introduction}

Ordinary Portland Cement (OPC) is the most widely used as construction material due to its high mechanical properties. However, OPC production consumes a large quantity of energy and emits greenhouse gases, i.e. carbon dioxide $\left(\mathrm{CO}_{2}\right)$, into the atmosphere. In order to mitigate the environmental problems, many researchers have focused on using environmentally-friendly materials with higher engineering properties than OPC. Geopolymer has been recognized as one of the most promising green materials for OPC replacement (Gomez-Zamorano et al. 2016; Zhang et al. 2016; Liew et al. 2016; Chokkha et al. 2017; Kaplan et al 2021 and Bayraktar 2021). "Geopolymer" is defined as an inorganic alumino-silicate powder based on geological material, which reacts with an alkaline activator to form a binder through a polycondensation process, as shown in Fig. 1. The geopolymer has an amorphous to semi-crystalline form with three-dimensional Si-O-Al polymeric networks.

(Fig. 1 here)

Several complex raw materials such as clay, fly ash (FA), slag, red mud, hydrate lime and other industrial waste have been used as a solid component in geopolymer (Nath et al. 2015; Badanoiu et al. 2015; Görhan et al. 2016; Vásquez et al. 2016; Tchakouté et al. 2016; Sore et al. 2016; Novais et al. 2016). Among these solid components, clay is an alumino-silicate material with total $70-90 \mathrm{wt} \%$ of $\mathrm{Al}_{2} \mathrm{O}_{3}$ and $\mathrm{SiO}_{2}$ in the form of Kaolinite phase. After calcination at $600-900^{\circ} \mathrm{C}$, the kaolinite crystal structure can be transformed into a highly reactive amorphous structure of metakaolin (MK)(Wang et al. 2005; Chokkha 2017 and Robayo-Salazar et al. 2016). Calcined clay, therefore, has been used as an alumino-silicate source in clay-based geopolymers. Many earlier reports showed that the compressive strength of claybased geopolymer was improved by the addition of the reactive metakaolin phase. This is due to a high surface area for dissolving in alkali reactant, leading to a geopolymerization reaction of geopolymer) (Ferone et al. 2015). 
A mixture of sodium hydroxide $(\mathrm{NaOH})$ and sodium silicate was used as alkali liquid reactant for dissolving alumino-silicate material to promote the high compressive strength of geopolymer through the geopolymerization reaction. Higher solubility of alumino-silicate powder can be obtained in higher molarity of alkali hydroxide. The alkali silicate is an activator for active- $\mathrm{SiO}_{2}$ polymerization in monomers, dimers, trimmers and oligomers, leading to improved microstructure and strength in the geopolymer. However, the cost of the specimen increases with an increasing concentration of $\mathrm{Na}_{2} \mathrm{SiO}_{3}$. The mixing process of $\mathrm{NaOH}$ and $\mathrm{Na}_{2} \mathrm{SiO}_{3}$ is complicated and makes the geopolymer more difficult to use (Heah et al. 2012 and Leong 2016).

Agricultural waste is one of the most promising materials for the production of geopolymers because of its high silica $\left(\mathrm{SiO}_{2}\right)$ content. After heat treatment, rice husk ash (RHA) contains $87-95 \mathrm{wt} . \%$ active-SiO 2 depending on the synthesis techniques. The active- $\mathrm{SiO}_{2}$ in natural husk ash can react with $\mathrm{NaOH}$ to form sodium silicate. Therefore, the natural husk ash can be used with $\mathrm{NaOH}$ activator to obtain high compressive strength for geopolymer (Hwang et al. 2015; Kaur et al. 2018 and Kaplan 2021).

This work focused on the synthesis of sodium silicate from RHA for use in making Metakaolin-based geopolymer with $\mathrm{SiO}_{2} / \mathrm{Al}_{2} \mathrm{O}_{3}$ ratios of 1.58 - 1.95. The compressive strength, structural phase, microstructure and geopolymerization were investigated by Instron machine, X-ray diffraction, Scanning electron microscope and FITR spectrometer, respectively.

\section{Materials And Methods}

\subsection{Preparation and characterization of starting materials.}

Ranong clay (Thailand source) and rice husk were used as starting raw materials. Rice husk was calcined at $750^{\circ} \mathrm{C}$ for 2 hours at a heating rate of $5^{\circ} \mathrm{C} / \mathrm{min}$ using the results from Simultaneous Thermal Analysis (STA). The chemical compositions of these materials were examined using X-ray fluorescence (XRF). The structural phase of calcined-Ranong clay and rice husk ash (RHA) was investigated by X-ray diffraction using Bruker D2 Advance with $\mathrm{CuKa}_{1}$ radiation. The analytical 2-theta range is $10^{\circ}-50^{\circ}$ with a step size of $0.02 \%$ step and a step time of $0.5 \mathrm{sec} / \mathrm{step}$. The JCPDS files (Joint Committee Powder Diffraction Standard) were used for phase identification. After achieving a pure phase of amorphous $\mathrm{SiO}_{2}$, it was sieved through a 60-mesh sieve and used as a solid component for geopolymer samples.

\subsection{Preparation of geopolymer samples}

The study was divided into three steps. In the first step, metakaolin was used as a solid component with a commercial sodium hydroxide $(\mathrm{NaOH})$ as an alkali activating agent. The composition of mixture was fixed with the alkali solution/ powder (S/P) ratio of $1 . \mathrm{NaOH}$ flakes were dissolved in de-ionized water (DI Water) with the $10 \mathrm{M}-\mathrm{NaOH}$ prior to mixing with aluminosilicate powder. The $\mathrm{SiO}_{2} / \mathrm{Al}_{2} \mathrm{O}_{3}$ ratio of $\mathrm{NaOH}$ based geopolymer calculated based on chemical composition from XRF data was 1.58. The $\mathrm{NaOH}$-based geopolymer specimen was prepared by mixing the metakaolin powder with $\mathrm{NaOH}$ solution until a 
homogeneous gel was achieved. The mixture was casted in a $50 \mathrm{~mm}$ cubic stainless-steel mold. All specimens were sealed with wrapping plastic film and cured at room temperature for 1 day. In the second step, commercial $\mathrm{Na}_{2} \mathrm{SiO}_{3}$ was mixed with $10 \mathrm{M}-\mathrm{NaOH}$, a geopolymer activator. The commercial $\mathrm{Na}_{2} \mathrm{SiO}_{3}$ solution was comprised of $16.3 \% \mathrm{Na}_{2} \mathrm{O}, 34.2 \% \mathrm{SiO}_{2}$ and $49.5 \% \mathrm{H}_{2} \mathrm{O}$. The stoichiometry of $\mathrm{NaOH}-\mathrm{Na}_{2} \mathrm{SiO}_{3}$ based geopolymer was studied in the $\mathrm{SiO}_{2} / \mathrm{Al}_{2} \mathrm{O}_{3}$ ratios of $1.67,1.76,1.86$ and 1.95. All compositions were prepared and characterized using the same conditions from Step 1. In the final step, the $\mathrm{SiO}_{2} / \mathrm{Al}_{2} \mathrm{O}_{3}$ ratios of $1.67,1.76,1.86$ and 1.95 based on the $\mathrm{NaOH}-\mathrm{SiO}_{2}$ activator system were studied and compared with $\mathrm{NaOH}-\mathrm{Na}_{2} \mathrm{SiO}_{3}$ based geopolymer system. $\mathrm{Na}_{2} \mathrm{SiO}_{3}$ solution was replaced with the reactive $\mathrm{SiO}_{2}$ from $\mathrm{RHA}$. The $\mathrm{Na}_{2} \mathrm{SiO}_{3}$ gel was prepared by stirring active $\mathrm{SiO}_{2}$ from $\mathrm{RHA}$ and $10 \mathrm{M} \mathrm{NaOH}$ solution until a homogeneous mixture was formed. Subsequently, all compositions were mixed with the metakaolin powder to form a geopolymer gel prior to casting and curing at the same conditions from a previous step.

\subsection{Characterization of hardened geopolymer samples}

Once the curing condition was completed, a compressive test was performed by Instron machine (series no. 5528) to evaluate the strength of all hardened geopolymer samples. The microstructure of the hardened samples was examined using a JEOL series JSM-6010LV scanning electron microscope (SEM) at $15 \mathrm{kV}$. The chemical composition of the geopolymer samples was analyzed by Energy Dispersive X-ray spectroscopy (EDX). In addition, a Bruker FITR spectrometer was used to evaluate the functional group of geopolymer samples. The FTIR spectra were recorded in the wave number between 400 and $2000 \mathrm{~cm}^{-1}$ with a resolution of $4 \mathrm{~cm}^{-1}$. The three-step experimental procedure of the present study is illustrated in Fig. 2.

(Fig. 2 here)

\section{Results And Discussion}

\subsection{Preparation and characterization of starting materials}

TGA-DTA curves of the rice husk are shown in Fig. 3. Endothermic peaks were observed at temperatures of $50^{\circ} \mathrm{C}, 315^{\circ} \mathrm{C}$ and $450^{\circ} \mathrm{C}$. The first endothermic peak at $50^{\circ} \mathrm{C}$ corresponded to the dehydration of adsorbed water with $7.46 \%$ mass loss. Other peaks at $315^{\circ} \mathrm{C}$ and $450^{\circ} \mathrm{C}$ corresponded to the combustion of major organic components such as hemicellulose, cellulose, lignin etc. in the rice husk with a total weight loss of $64.61 \%$. From Fig. 3 , the end set temperature is above $650^{\circ} \mathrm{C}$. The calcination temperature of rice husk, therefore, was assigned as $750^{\circ} \mathrm{C}$, which was high enough to form a reactive amorphous $\mathrm{SiO}_{2}$.

(Fig. 3 here)

\subsection{Structural investigations of starting materials}


Figure 4 shows the X-ray diffraction analysis of Ranong clay, calcined Ranong clay and rice hush ash after calcination at $750^{\circ} \mathrm{C}$ for $2 \mathrm{hrs}$ in air. Kaolinite, muscovite and quartz with the JCPDS series of 010527, 01-1098 and 70-3755, respectively, were detected in Ranong clay. After calcination at $750^{\circ} \mathrm{C}$, the major peak of kaolinite at $2 \theta \approx 2.35^{\circ}$ disappeared and an amorphous hump was observed between $2 \theta \approx$ $15-34^{\circ}$, which is correspondent to the formation of the metakaolin phase. From Fig. 4, the XRD pattern of RHA shows the major amorphous hump of active- $\mathrm{SiO}_{2}$ phase between $2 \theta$ of $15-40^{\circ}$ together with the trace of crystalline quartz.

(Fig. 4. here)

\subsection{Chemical composition of starting materials}

The chemical compositions of starting materials quantified by X-ray fluorescence (XRF) technique are shown in Table 1. The major components in calcined Ranong clay are $59.12 \mathrm{wt.} \% \mathrm{SiO}_{2}$ and (37.37 wt.\%) $\mathrm{Al}_{2} \mathrm{O}_{3}$, similar to the theoretical $\mathrm{SiO}_{2}$ and $\mathrm{Al}_{2} \mathrm{O}_{3}$ percentage of the metakaolin phase in kaolinite material. Meanwhile, $\mathrm{RHA}$ is mostly composed of $\mathrm{SiO}_{2}$ ( $94 \mathrm{wt}$.\%), indicating a great active-silica source of RHA. From the chemical analysis, the stoichiometric ratios of $\mathrm{SiO}_{2} / \mathrm{Al}_{2} \mathrm{O}_{3}$ were calculated for preparing geopolymer samples.

Table 1

Chemical composition of starting raw materials

\begin{tabular}{|c|c|c|c|c|c|c|c|c|}
\hline & $\mathrm{SiO}_{2}$ & $\mathrm{Al}_{2} \mathrm{O}_{3}$ & $\mathrm{P}_{2} \mathrm{O}_{5}$ & $\mathrm{~K}_{2} \mathrm{O}$ & $\mathrm{CaO}$ & MnO & $\mathrm{Fe}_{2} \mathrm{O}_{3}$ & Other \\
\hline Calcined Ranong clay & 59.12 & 37.37 & N.D. & 1.80 & N.D. & 0.15 & 1.46 & 0.10 \\
\hline Rice husk ash & 93.56 & 0.24 & 1.34 & 2.22 & 1.74 & 0.35 & 0.31 & 0.24 \\
\hline
\end{tabular}

XRD pattern of the metakaolin phase and rice husk ash was observed in the range of $2 \theta\left(15-34^{\circ}\right)$ and $2 \theta$ of $15-40^{\circ}$, respectively. The new position of the broad peak occurred in all geopolymer samples, as shown in Fig. 5 . The broad peak at $2 \theta$ between $20-40^{\circ}$ was typically observed in all geopolymer samples, indicating an intermediate state between the amorphous and semi-crystalline phase in geopolymer samples. The center of the hump was shifted to higher $2 \theta$ of $29.5^{\circ}$ related to formation of alumino-silicate amorphous phase. The shift of the peak position was also contributed to the geopolymetric reaction in all specimens.

(Fig. 5 here)

\subsection{FT-IR spectra of geopolymer samples}

The FT-IR spectra of starting materials and geopolymer samples are shown in Fig. 6. The identified absorption peaks and characteristic bands of each spectrum are tabulated in Table 2. For metakaolin 
powder, the significant broad band was detected at $1040 \mathrm{~cm}^{-1}$ which is attributed to the asymmetric stretching vibration of $\mathrm{Si}-\mathrm{O}-\mathrm{Si}$. The peak was also found at $550 \mathrm{~cm}^{-1}$, which is ascribed to the symmetric stretching vibration of Si-O-Si and Si-O-Al. In addition, the distinct peak observed at $440 \mathrm{~cm}^{-1}$ was related to the bending vibration of Si-O.

Table 2

Characteristic FT-IR board bands of geopolymer specimens.

\begin{tabular}{|ll|}
\hline $\begin{array}{l}\text { Characteristic band } \\
\left(\mathbf{c m}^{-\mathbf{1}} \mathbf{)}\right.\end{array}$ & Assigned to \\
\hline 3345 & Stretching vibration of $-\mathrm{OH}$ \\
\hline $1645-1750$ & Bending vibration of $\mathrm{H}-\mathrm{O}-\mathrm{H}$ \\
\hline 1450 & Stretching vibration of $-\mathrm{C}-\mathrm{O}$ \\
\hline $900-1200$ & $\begin{array}{l}\text { Asymmetric stretching vibration of Si-O-Si in raw material and Si-O-Al in } \\
\text { geopolymer samples }\end{array}$ \\
\hline 790 & Stretching vibration of Si-O-Si \\
\hline 680 & Symmetric stretching vibration of Si-O-Si and Si-O-Al \\
\hline 550 & Symmetric stretching vibration of Si-O-Si and Si-O-Al \\
\hline 440 & Bending vibration of Si-O \\
\hline
\end{tabular}

For the geopolymer samples, the appearance of broad band at $1700 \mathrm{~cm}^{-1}$ corresponded to the bending vibration of $\mathrm{H}-\mathrm{O}-\mathrm{H}$ water bonding. The $\mathrm{H}-\mathrm{O}-\mathrm{H}$ bonds are correlated with the reduction of mechanical properties. The absorption peak at $1450 \mathrm{~cm}^{-1}$ was related to asymmetric stretching of the $\mathrm{O}-\mathrm{C}-\mathrm{O}$ bond, corresponding to carbonation during the curing process. The main absorption peak around 900-1200 $\mathrm{cm}^{-1}$ involved with the asymmetrical stretching vibrations of Si-O-Al or Si-O-Si bonds. However, as the replacement of $\mathrm{Al}$ into the Si-site increases, the peak was shifted to a lower wave number. From this result, the position of the Si-O-Si band at $1040 \mathrm{~cm}^{-1}$ in the metakaolin powder shifted to a lower wave number $\left(940-970 \mathrm{~cm}^{-1}\right)$ in the geopolymer samples. The result was related to the partial replacement of Si by Al in the geopolymer gel structure, suggesting that the geopolymer degree was strengthened. Other absorption bands appeared at 550 and $440 \mathrm{~cm}^{-1}$, representing the tetrahedral aluminum stretching bands and bending vibration of $\mathrm{Si}-\mathrm{O}-\mathrm{Si} / \mathrm{Si}-\mathrm{O}-\mathrm{Al}$, respectively. By increasing the $\mathrm{SiO}_{2} / \mathrm{Al}_{2} \mathrm{O}_{3}$ ratio, the intensity of bands tends to decrease, which is associated with the increasing of geopolymerization degree.

(Fig. 6 here)

\subsection{Compressive strength}

Figure 7 shows the compressive strength of all specimens after curing for $24 \mathrm{hrs}$. The compressive strength of geopolymer samples was positively developed by mixing $\mathrm{Na}_{2} \mathrm{SiO}_{3}$ in the $\mathrm{SiO}_{2} / \mathrm{Al}_{2} \mathrm{O}_{3}$ ratios of 
1.67 - 1.95. This contributed to the role of active- $\mathrm{SiO}_{2}$ in the $\mathrm{Na}_{2} \mathrm{SiO}_{3}$ solution on the formation of geopolymer chain. However, the increasing active- $\mathrm{SiO}_{2}$ by $\mathrm{Na}_{2} \mathrm{SiO}_{3}$ enhanced the unit cost of geopolymer due to the high price of $\mathrm{Na}_{2} \mathrm{SiO}_{3}$. The replacement of active- $\mathrm{SiO}_{2}$ from $\mathrm{Na}_{2} \mathrm{SiO}_{3}$ by active-SiO${ }_{2}$ from RHA showed a positively significant effect at the $\mathrm{SiO}_{2} / \mathrm{Al}_{2} \mathrm{O}_{3}$ ratio of 1.95 . The highest compressive strength of about $25 \mathrm{MPa}$ was achieved from the geopolymer with active- $\mathrm{SiO}_{2}$ from $\mathrm{RHA}$, which is comparable to the compressive strength of geopolymer with active- $\mathrm{SiO}_{2}$ in $\mathrm{Na}_{2} \mathrm{SiO}_{3}$ at the $\mathrm{SiO}_{2} / \mathrm{Al}_{2} \mathrm{O}_{3}$ ratio of 1.86 . The compressive strength of geopolymer from $\mathrm{RHA}$ at the $\mathrm{SiO}_{2} / \mathrm{Al}_{2} \mathrm{O}_{3}$ ratio 1.95 was also beyond the minimum requirement of the compressive strength from OPC. The use of RHA as a resource of active$\mathrm{SiO}_{2}$ in geopolymer, therefore, can reduce almost $85 \%$ of the unit cost for geopolymer making as shown in Fig. 8.

(Fig. 7 here)

(Fig. 8 here)

\subsection{Microstructure of geopolymer samples}

Fig. 9 shows the SEM micrographs of the geopolymer samples with all $\mathrm{SiO}_{2} / \mathrm{Al}_{2} \mathrm{O}_{3}$ ratios. The various of pore size and particles were obtained in the geopolymer sample. The small plate-like and needle-like structures with high porosity were observed in the geopolymer with the $\mathrm{SiO}_{2} / \mathrm{Al}_{2} \mathrm{O}_{3}$ ratios below 1.86 . The compacted structures and small number of pores without needle-like particles were obtained at high ratios of $\mathrm{SiO}_{2} / \mathrm{Al}_{2} \mathrm{O}_{3}$ (1.86 and 1.95), indicating the complete geopolymer formation with high compressive strength as mentioned in previous section. In addition, the percentage of elements detected by EDX analysis showed slightly different in the weight of $\mathrm{Al}$ and $\mathrm{Si}$, indicating that the excess $\mathrm{SiO}_{2}$ was not included in the $\mathrm{SiO}_{2} / \mathrm{Al}_{2} \mathrm{O}_{3}$ ratio of 1.95 . Hence, the strong bonding of $\mathrm{Si}-\mathrm{O}-\mathrm{Al}$ chain can be formed in the geopolymer samples.

(Fig. 9 here)

\section{Conclusions}

The experimental work in this study aimed to use RHA as an alkali silicate activator replacement in the system of metakaolin-based geopolymer. The effects of RHA on the mechanical properties, structural phase and functional group of geopolymer can be drawn as below:

1. After curing at room temperature for $24 \mathrm{hrs}$, the RHA activator based geopolymer with the $\mathrm{SiO}_{2} / \mathrm{Al}_{2} \mathrm{O}_{3}$ ratio of 1.95 showed the highest compressive strength (25 MPa), which is higher than the minimum requirement for Ordinary Portland Cement (OPC). 
2. The formation of alumino-silicate amorphous phase in geopolymer from RHA indicated the reaction of RHA with other precursor during geopolymerization.

3. The downward shift of Si-0-Si main functional group at $940-970 \mathrm{~cm}^{-1}$ suggested to the partial replacement of Si by Al to form Si-O-Al chain in geopolymer, leading to higher mechanical strength of geopolymer from RHA.

Therefore, the enhancement of compressive strength by using RHA instead of sodium silicate activator in metakaolin-based geopolymer in this work offered the intelligent method for eliminating sodium silicate solution from the geopolymer component and minimized the manufacturing cost of the geopolymer fabrication process.

\section{Declarations}

\section{Acknowledgement}

This research was financially supported by the Suranaree University of Technology Research and Development Fund. We also thank Suranaree University of Technology (SUT) for facilitating the development of part of the research in our work.

Authors Contributions Siriwan Chokkha contributed to the writing of the article, literature review, Designed-performed the experiment and analyed the results. Jiratchaya Ayawanna contributed to literature review. Anurat Poowancum contributed to design the experiment.

Funding This research was financially supported by the Suranaree University of Technology Research and Development Fund.

Availability of data and materials The datasets generated during and/or analysed during the current study are available from the corresponding author on reasonable request.

Ethical Approval Not applicable.

Consent to Participate Not applicable.

Consent to Publish The participant has consented to the submission of the case report to the journal.

Competing Interests The authors declare no competing interests.

\section{References}

1. Badanoiu Al, Al Saadi THA, Stoleriu S, Voicu G (2015) Preparation and characterization of foamed geopolymers from waste glass and red mud. Constr Build Mater 84:284-293.

https://doi.org/10.1016/j.conbuildmat.2015.03.004 
2. Bayraktar OY (2021) Possibilities of disposing silica fume and waste glass powder, which are environmental wastes, by using as a substitute for Portland cement. Environ Sci Pollut Res 28:16843-16854. https://doi.org/10.1007/s11356-020-12195-9

3. Chokkha S (2017) Effect of Fly ash on Compressive strength of Metakaolin based Geopolymer. Appl. Mech. Mater. 873: 170-175. https://doi.org/10.4028/www.scientific.net/AMM.873.170

4. Chokkha S, Phetnat P, Chandadi W, Srisitthigul M (2017) Use of Waste Glass as a Reinforce Material in Calcined-kaolin Based Geopolymer. Key Eng. Mater. 751: 556-562. https://doi.org/10.4028/www.scientific.net/KEM.751.556

5. Ferone C, Liguori B, Capasso I, Colangelo F, Cioffi R, Cappelletto E, Di Maggio R (2015) Thermally treated clay sediments as geopolymer source material. Appl Clay Sci 107:195-204. https://doi.org/10.1016/j.clay.2015.01.027

6. Gomez-Zamorano LY, Vega-Cordero E, Struble L (2016) Composite geopolymers of metakaolin and geothermal nanosilica waste. Constr Build Mater 115:269-276.

https://doi.org/10.1016/j.conbuildmat.2016.03.002

7. Görhan G, Aslaner R, Şinik O (2016) The effect of curing on the properties of metakaolin and fly ashbased geopolymer paste. Comp Part B 97:329-335. https://doi.org/10.1016/j.compositesb.2016.05.019

8. Heah CY, Kamarudin H, Mustafa Al Bakri AM, Bnhussain M, Luqman M, Khairul Nizar I, Ruzaidi CM, Liew YM (2012) Study on solids-to-liquid and alkaline activator ratios on kaolin-based geopolymers. Constr Build Mater 35:912-922. https://doi.org/10.1016/j.conbuildmat.2012.04.102

9. Hwang CL, Huynh TP (2015) Effect of alkali-activator and rice husk ash content on strength development of fly ash and residual rice husk ash-based geopolymers. Constr Build Mater 101:1-9. https://doi.org/10.1016/j.conbuildmat.2015.10.025

10. Kaplan G, Elmekahal MAS (2021) Microstructure and Durability Properties of Lightweight and HighPerformance Sustainable Cement-Based Composites with Rice Husk Ash. Environ Sci Pollut Res 28:52936-52962. https://doi.org/ 10.21203/rs.3.rs-337672/v1

11. Kaplan G, Gulcan A, Cagdas B, Bayraktar OY (2021) The impact of recycled coarse aggregates obtained from waste concretes on lightweight pervious concrete properties. Environ Sci Pollut Res 28:17369-17394. https://doi.org/ 10.1007/s11356-020-11881-y

12. Kaur K, Singh J, Kaur M (2018) Compressive strength of rice husk ash based geopolymer: The effect of alkaline activator. Constr Build Mater 169:188-192.

https://doi.org/10.1016/j.conbuildmat.2018.02.200

13. Leong HY, Ong DEL, Sanjayan JG, Nazari A (2016) The effect of different $\mathrm{Na}_{2} \mathrm{O}$ and $\mathrm{K}_{2} \mathrm{O}$ ratios of alkali activator on compressive strength of fly ash based-geopolymer. Constr Build Mater 106:500511. https://doi.org/10.1016/j.conbuildmat.2015.12.141

14. Liew YM, Heah CY, Al Bakri MM, Abdullah, Kamarudin H (2016) Structure and properties of claybased geopolymer cements: A review. Prog Mater Sci 83:595-629. https://doi.org/10.1016/j.pmatsci.2016.08.002 
15. Nath P, Sarker PK (2015) Use of OPC to improve setting and early strength properties of low calcium fly ash geopolymer concrete cured at room temperature. Cem Concr Comp 55:205-214. https://doi.org/10.1016/j.cemconcomp.2014.08.008

16. Novais RM, Ascensão G, Seabra MP, Labrincha JA (2016) Waste glass from end-of-life fluorescent lamps as raw material in geopolymers. Waste Manag 52:245-255. https://doi.org/10.1016/j.wasman.2016.04.003

17. Robayo-Salazar RA, De Mejía R, Puertas F (2016) Effect of metakaolin on natural volcanic pozzolanbased geopolymer cement. Appl Clay Sci 132-133:491-497. https://doi.org/10.1016/j.clay.2016.07.020

18. Sore SO, Messan A, Prud'homme E, Escadeillas G, Tsobnang F (2016) Synthesis and characterization of geopolymer binders based on local materials from Burkina Faso-Metakaolin and rice husk ash. Constr Build Mater 124:301-311. https://doi.org/10.1016/j.conbuildmat.2016.07.102

19. Tchakouté HK, Rüscher $\mathrm{CH}$, Kong S, Kamseu E, Leonelli C (2016) Geopolymer binders from metakaolin using sodium waterglass from waste glass and rice husk ash as alternative activators: A comparative study. Constr Build Mater 114:276-289.

https://doi.org/10.1016/j.conbuildmat.2016.03.184

20. Vásquez A, Cárdenas V, Robayo-Salazar RA, Mejía de Gutiérrez R (2016) Geopolymer based on concrete demolition waste. Adv Powder Tech 27:1173-1179.

https://doi.org/10.1016/j.apt.2016.03.029

21. Wang H, Li H, Yan F (2005) Synthesis and mechanical properties of metakaolinite-based geopolymer. Coll Surf -A Physicochem Eng Asp 268:1-6. https://doi.org/10.1016/j.colsurfa.2005.01.016

22. Zhang ZH, Zhu HJ, Zhou CH, Wang H (2016) Geopolymer from kaolin in China: An overview. Appl Clay Sci 119:31-41. https://doi.org/10.1016/j.clay.2015.04.023

\section{Figures}




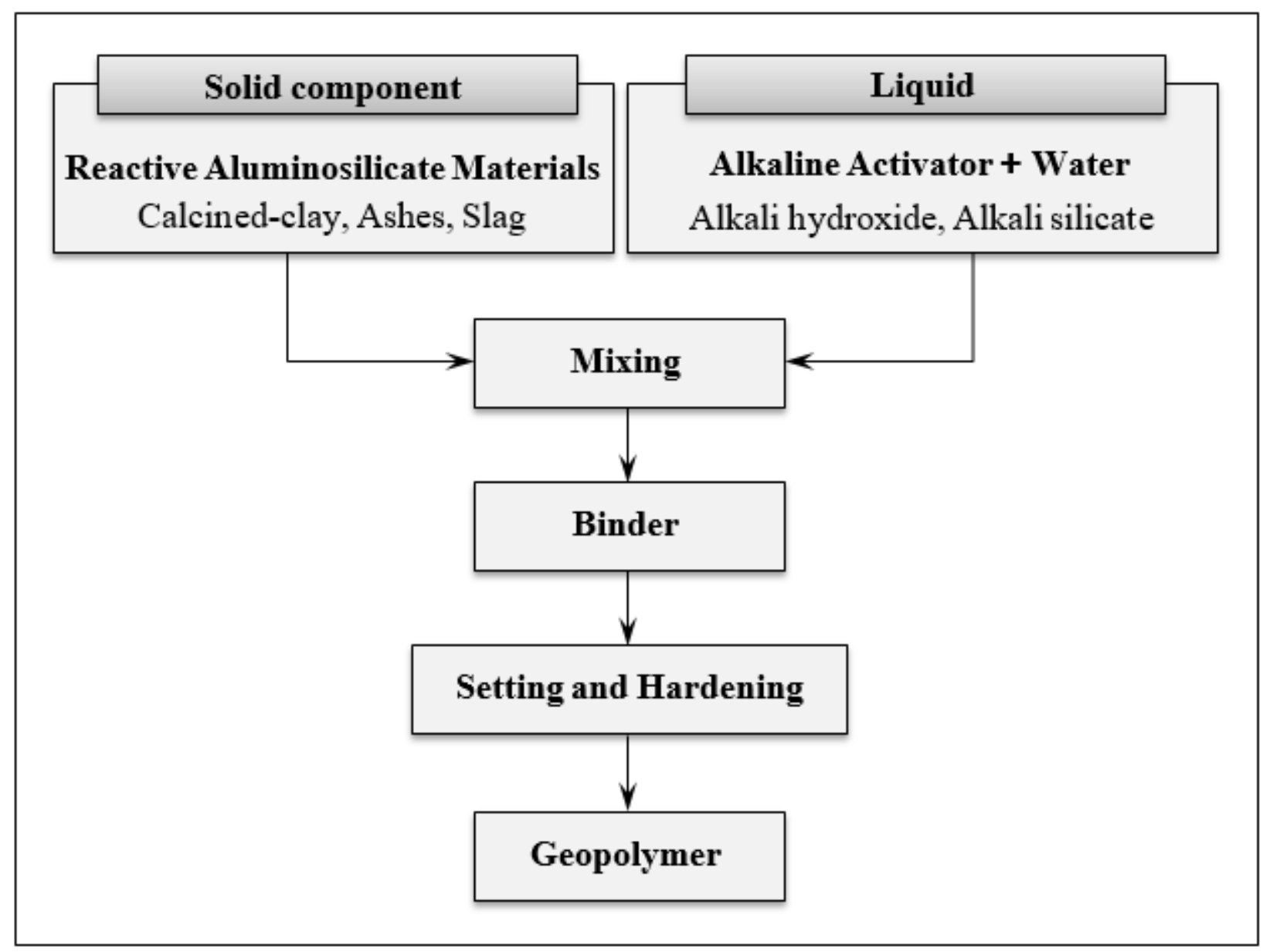

Figure 1

Production process of geopolymers (Liew et al. 2016). 


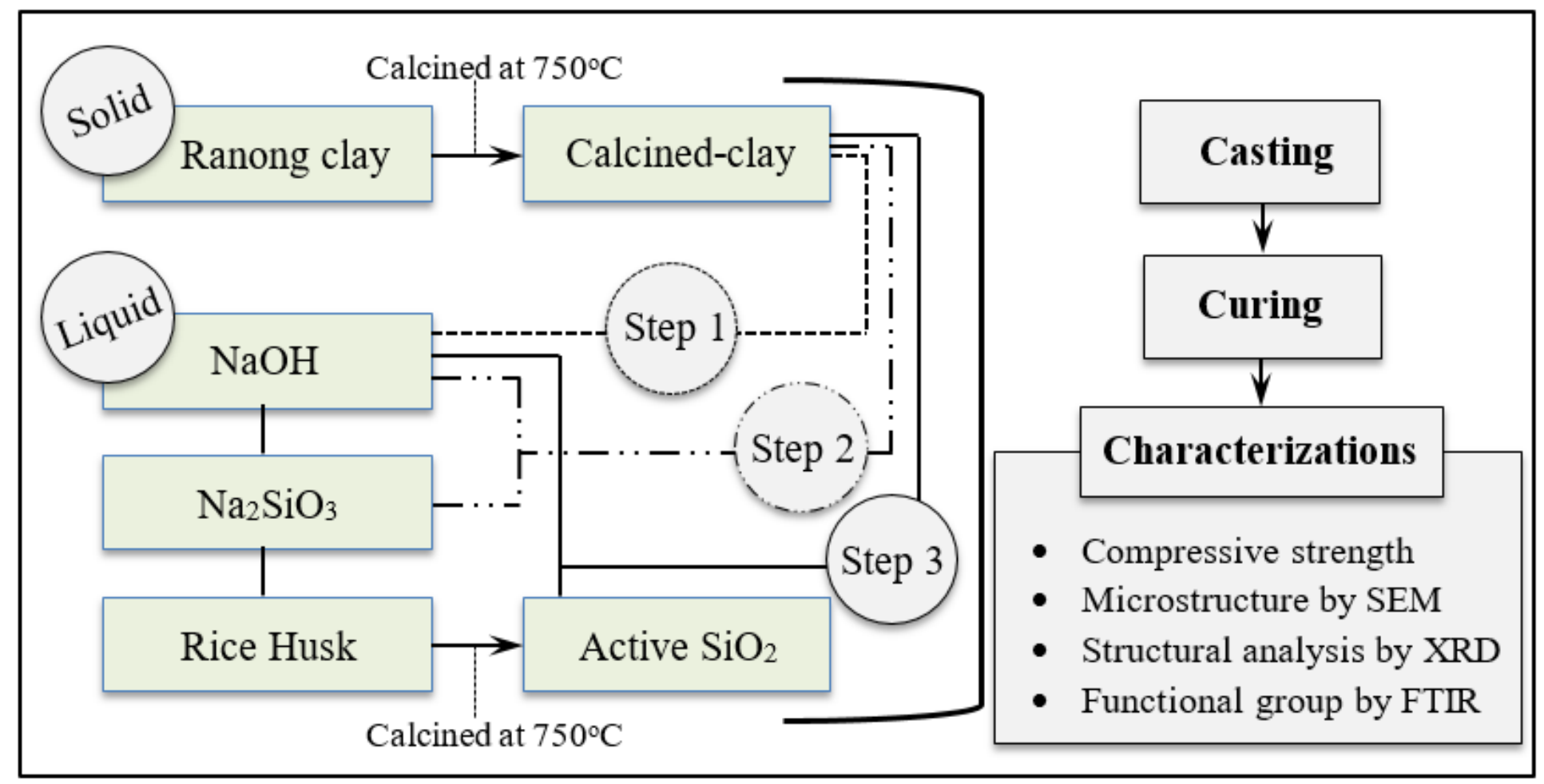

Figure 2

Flow diagram for the production of geopolymer sample. 


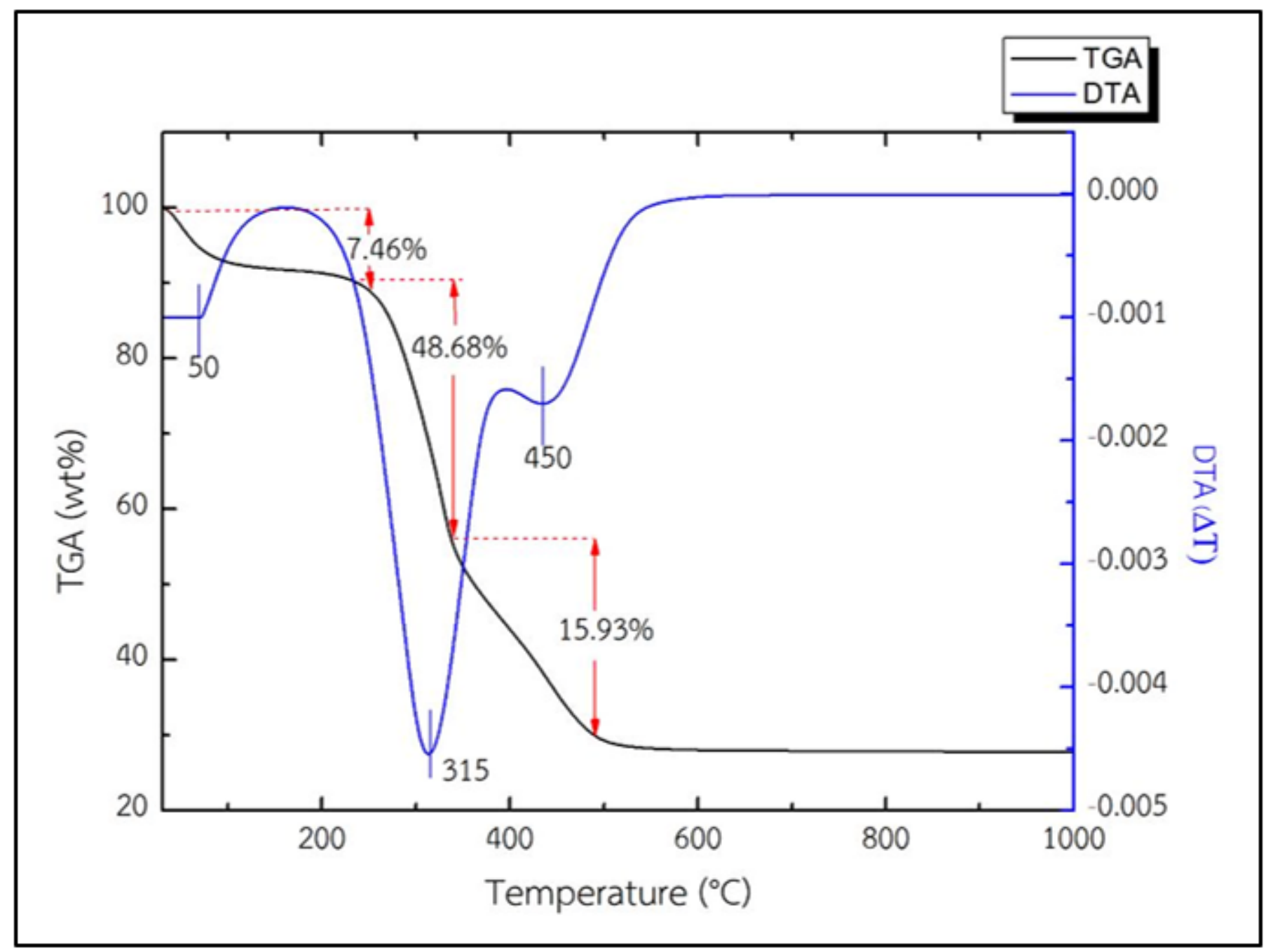

Figure 3

STA analysis of rice husk. 


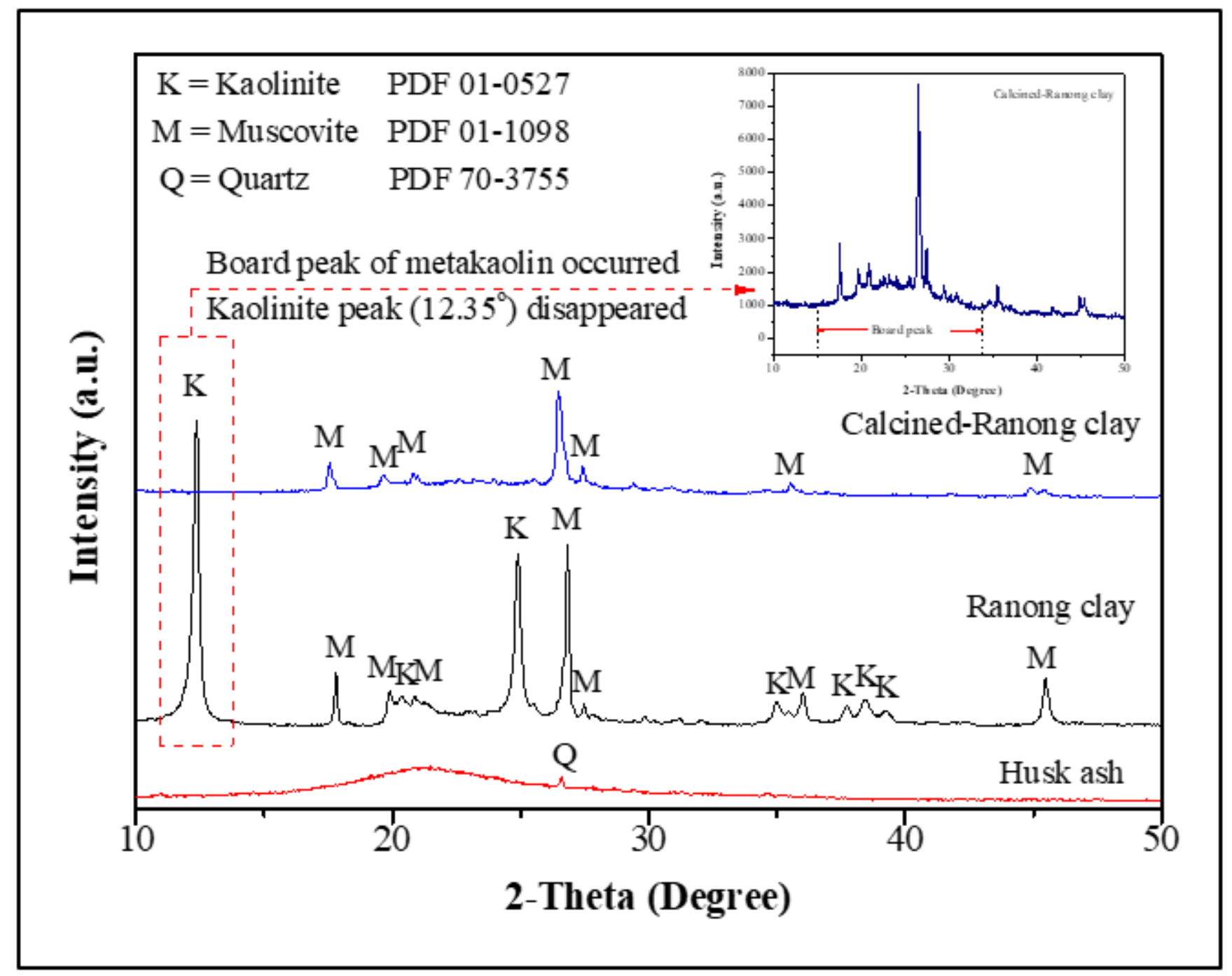

Figure 4

XRD diffraction pattern of starting raw materials after calcined at $750^{\circ} \mathrm{C}$. 


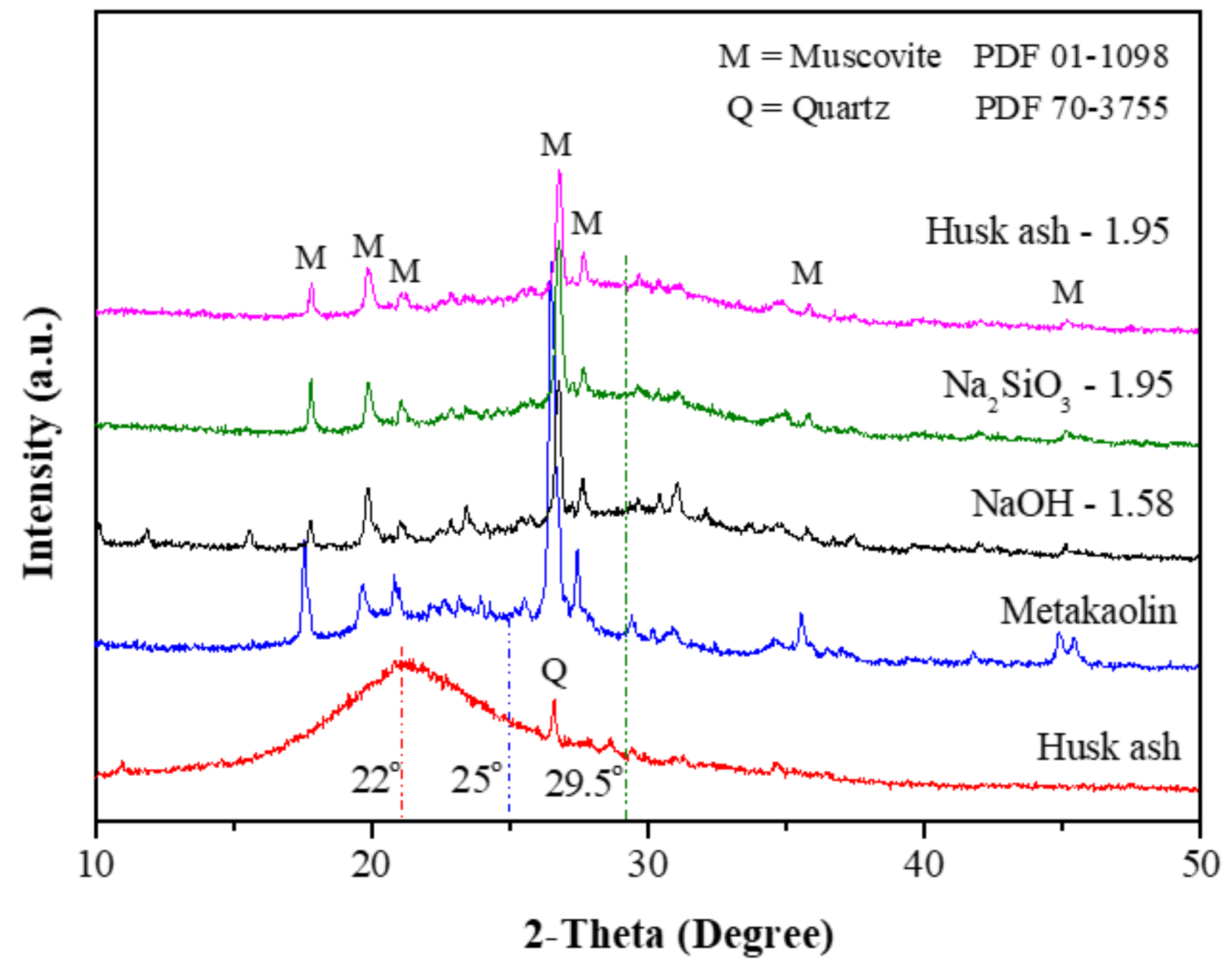

Figure 5

XRD pattern of geopolymer samples. 


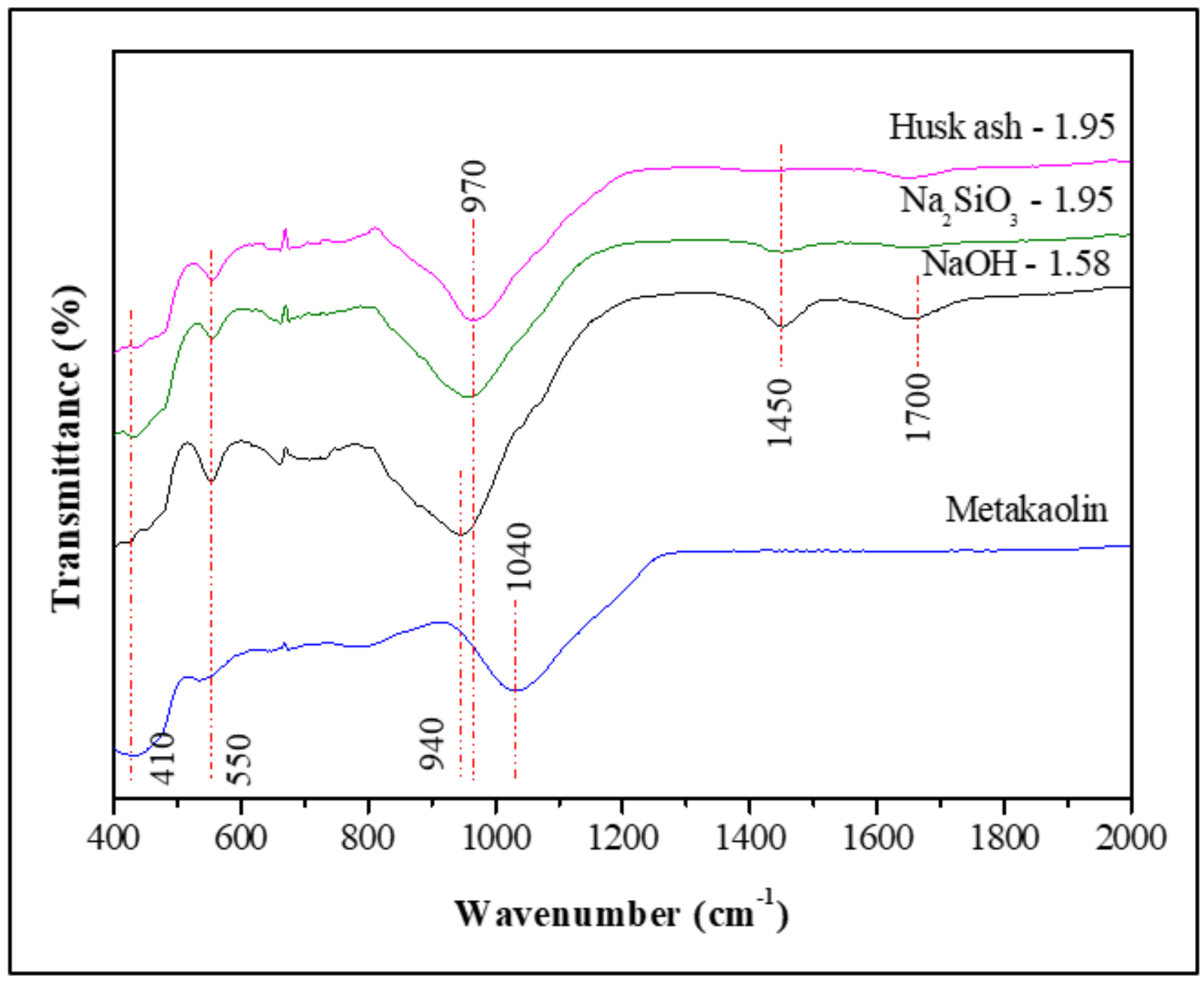

Figure 6

FT-IR spectra of geopolymer samples. 


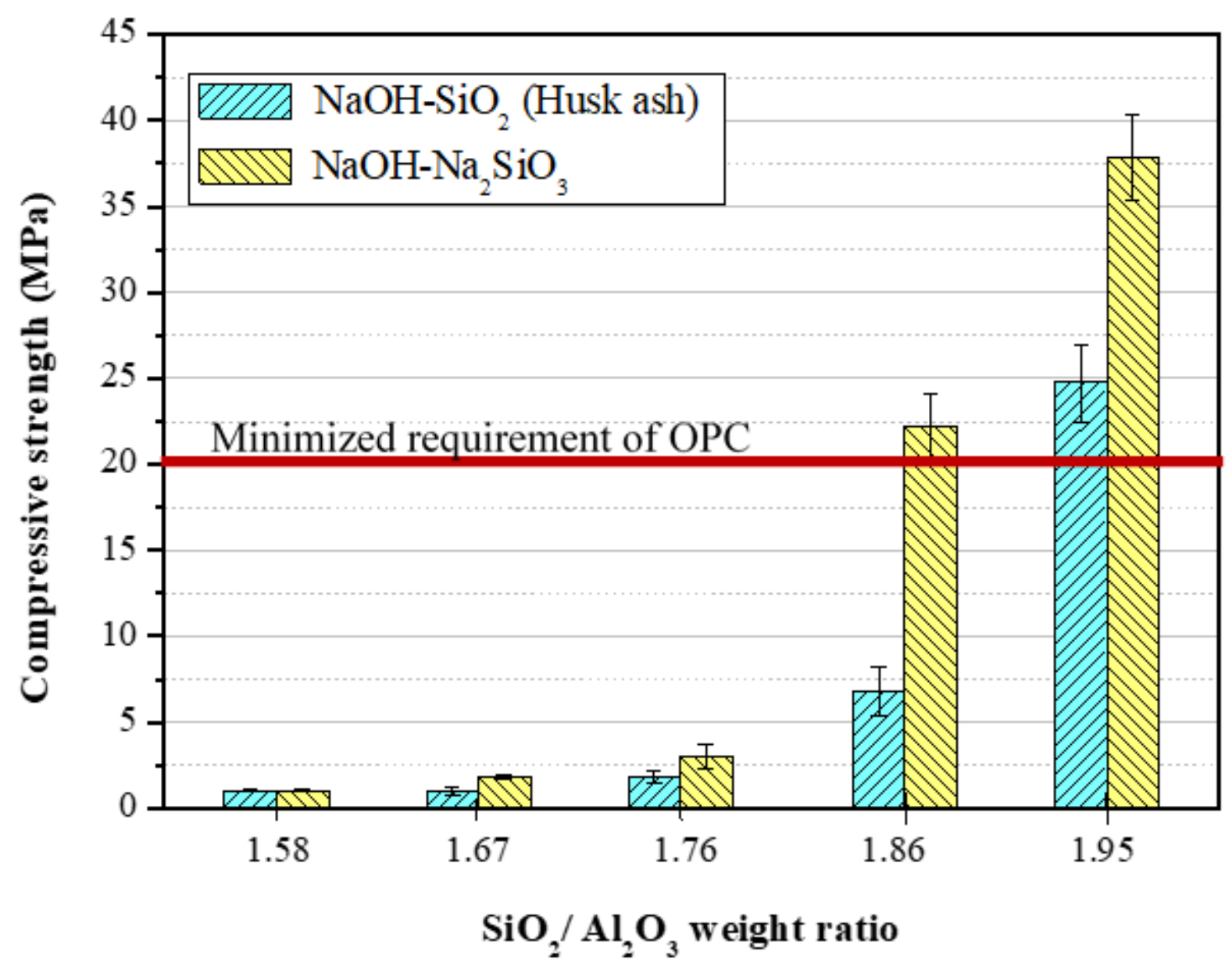

Figure 7

The compressive strength comparison of husk ash and $\mathrm{Na}_{2} \mathrm{SiO}_{3}$ specimens. 


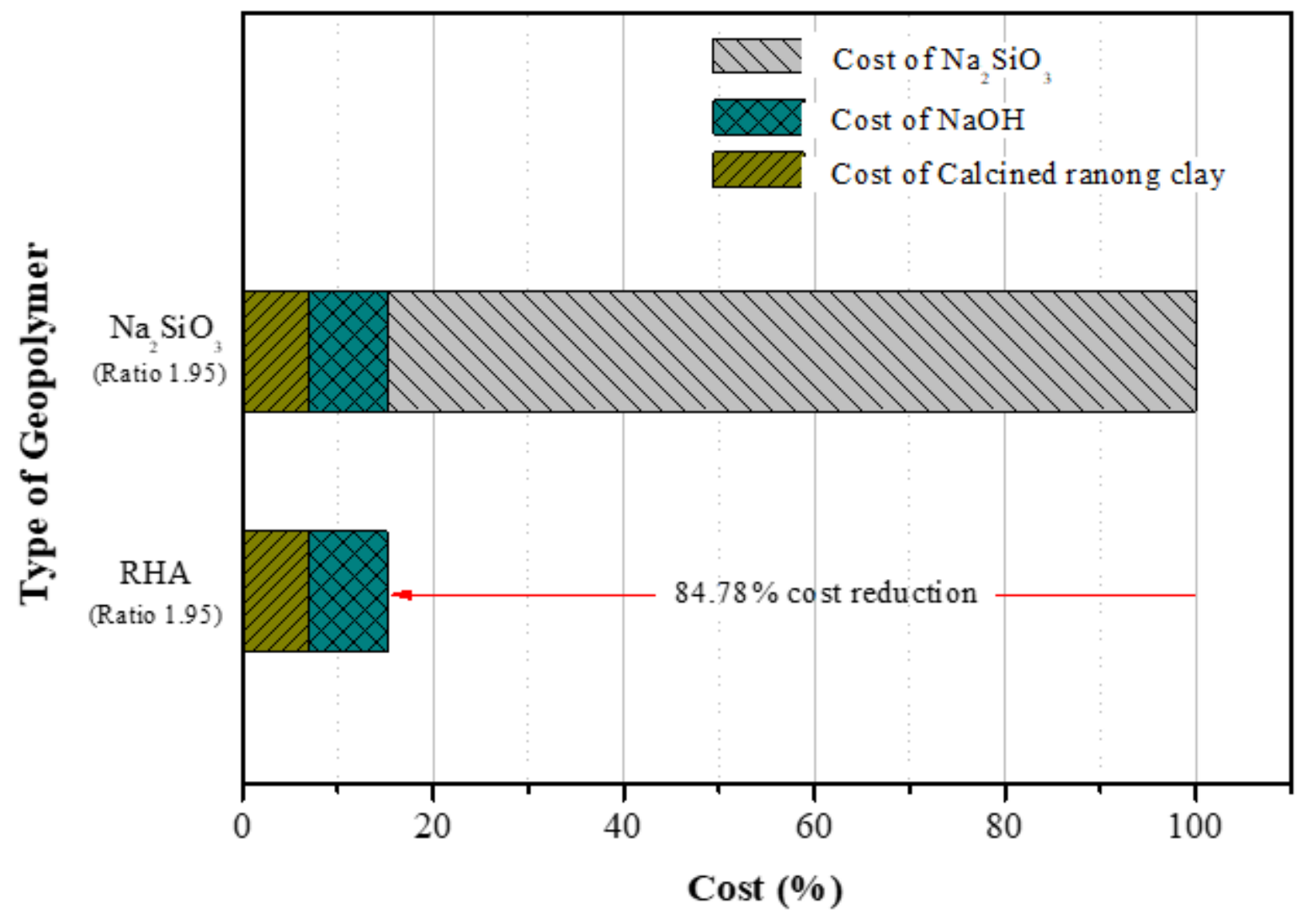

Figure 8

Estimated cost of geopolymer $\left(1.95 \%\right.$ of $\mathrm{SiO}_{2} / \mathrm{Al}_{2} \mathrm{O}_{3}$ ratio $)$ 


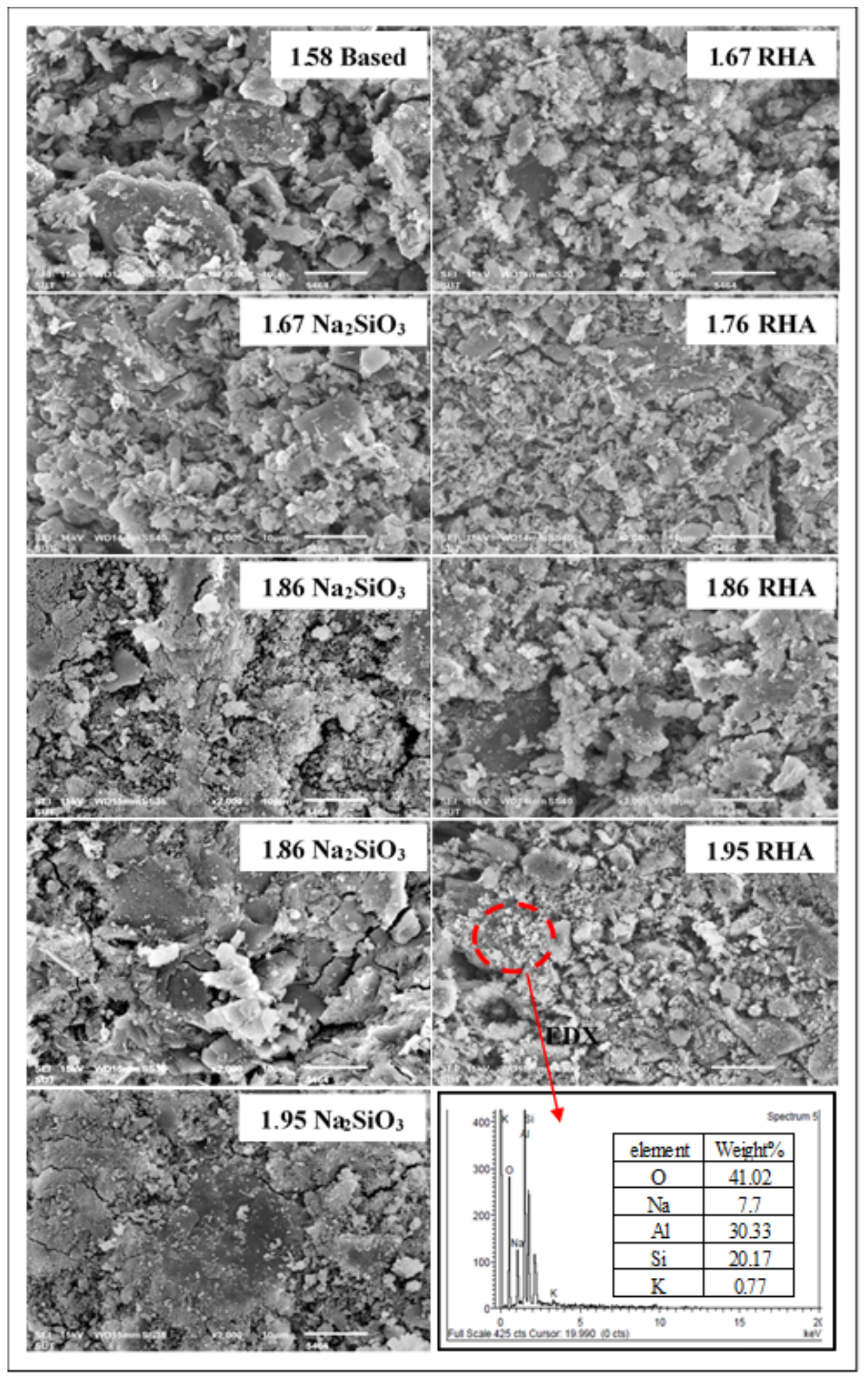

Figure 9

SEM micrograph of geopolymer samples from different resources of active-SiO ${ }_{2}$ and the ratios of $\mathrm{SiO}_{2} / \mathrm{Al}_{2} \mathrm{O}_{3}$. 